TI 2013-141/VIII

Tinbergen Institute Discussion Paper

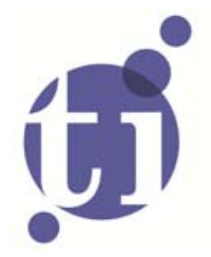

tinbergen
institute

\title{
From Islands to Hubs of Innovation: Connecting Innovative Regions
}

\author{
Andrea Caragliu' \\ Peter Nijkamp²
}

1 Politecnico di Milano, Italy;

2 Faculty of Economics and Business Administration, VU University Amsterdam, and Tinbergen Institute, The Netherlands. 
Tinbergen Institute is the graduate school and research institute in economics of Erasmus University Rotterdam, the University of Amsterdam and VU University Amsterdam.

More TI discussion papers can be downloaded at http://www.tinbergen.nl

Tinbergen Institute has two locations:

Tinbergen Institute Amsterdam

Gustav Mahlerplein 117

1082 MS Amsterdam

The Netherlands

Tel.: +31(0)205251600

Tinbergen Institute Rotterdam

Burg. Oudlaan 50

3062 PA Rotterdam

The Netherlands

Tel.: +31(0)10 4088900

Fax: $+31(0) 104089031$

Duisenberg school of finance is a collaboration of the Dutch financial sector and universities, with the ambition to support innovative research and offer top quality academic education in core areas of finance.

DSF research papers can be downloaded at: http://www.dsf.nl/

Duisenberg school of finance

Gustav Mahlerplein 117

1082 MS Amsterdam

The Netherlands

Tel.: +31(0)20 5258579 
Andrea Caragliu ${ }^{{ }^{*}}$, Peter Nijkamp ${ }^{\ddagger}$ **

\title{
From islands to hubs of innovation: connecting innovative regions
}

* Tinbergen Institute, The Netherlands

\begin{abstract}
This paper enters the debate on the islands of innovation through the lens of the standard Lucas (1988) growth model. It begins with a review of the theoretical details of the model and of the ensuing main empirical results, which can be identified when estimating such model on a sample of 261 EU27 NUTS2 regions. Next, empirical results are interpreted in the light of recent EU innovation and education policies.

Our results point to the paramount importance of taking into account patterns of connectivity between "islands" of innovation and other regions. On the basis of our empirical estimates, we claim that future further concentration of innovative activity could achieve maximum returns by enhancing connectivity between spatial innovation leaders and lagging regions. This situation may be characterised as targeting "hubs", rather than "islands", of innovation, and is in agreement with "open innovation policy".

JEL classification codes: C21, E24, R11

Keywords: human capital, cognitive capital, knowledge spillovers, islands of innovation.

$\S$ Politecnico di Milano - Building Environment ${ }^{¥}$ Faculty of Economics and Business Administration Science and Technology

Piazza Leonardo 32 Department of Spatial Economics

20133 Milan (MI)

Italy

${ }^{*}$ Corresponding author VU University Amsterdam

De Boelelaan 1105

1081 HV Amsterdam

The Netherlands
\end{abstract}




\section{Introduction and motivation}

Recent data on the spatial distribution of educated workers clearly show that three main trends are currently taking place in European regions:

- A growing regional concentration of an educated labour force in a few hotspots (islands) of innovation (Hilpert, 1992; Zucker and Darby, 2007);

- A growing probability for individuals within each region to meet people with different levels of education (Caragliu and Nijkamp, 2011);

- A rising accessibility in terms of knowledge and information through virtual networks between geographically disjoint areas (Tranos et al., 2011).

Various data suggest an increase in both cross-regional and intraregional differentials of human capital-rich labour force. ${ }^{1}$ This stylized fact is in line with recent advanced literature on the increasing process of concentration of skilled labour in space. In fact, evidence-based research finds that if there are economies of scale, the major driver of such concentration process is formed by more concentrated skilled labour, which tends to be simply more productive, thereby fostering further attraction of skilled labour from outside (Acemoglu, 1996; Rauch, 1993). European cities offer a similar picture, with a few hotspots of innovation and creativity increasingly attracting knowledge-intensive labour (Caragliu et al., 2012; Nijkamp, 2010); these findings are also in line with a rich literature on localized knowledge externalities typical of innovation clusters (Porter, 1990, 1998, and 2000; Saxenian, 1994).

A convincing literature gives this process the name of islands of innovation (Hilpert, 1992; Trippl, forthcoming; Hilpert, forthcoming). In the present paper we move a step further along the lines set by these studies and look for the conditions which allow the emergence of hubs, and not islands, of innovation. In fact, although pure concentration patterns are found to be optimal for the region where the educated labour migrates, no convincing explanation exists on what happens to regions from which skilled outward migration originates. This issue reconnects to the literature on the brain drain (see, e.g., Docquier et al., 2010; see also Gibson and McKenzie, 2011 for a recent overview of this topic), which usually finds that regions and countries which lose skilled labour face damage through several distinct channels (for example the loss of human capital, a pattern of decreasing productivity, and the emergence of lower innovation rates in sending countries and regions; see for instance Marchiori et al., 2009). The case for improving the connectivity (i.e. with the aim to avoid "splendid isolation") of islands of innovation is also made in Kourtit et al. (2011).

It becomes therefore fundamental to correctly assess the potential long run effects of a human capital-rich labour force in space for sending regions. This paper offers a new perspective on this point, on the basis of the empirical results shown in Caragliu and Nijkamp (2011). The paper is structured as follows. In Section 2 a set of stylized facts is presented with the aim of framing the emergence of islands of innovation in the European regional context, while at the same time providing the rationale for this work. In Section 3 the theoretical model employed in Caragliu and Nijkamp (2011) is briefly summarized. The results of the empirical validation of the model are presented in Section 4. Section 5 critically discusses the policy implications of such results. Finally, Section 6 concludes.

\section{Stylized facts}

Recent figures suggest that in most OECD countries education levels are on average increasing: more and more people are enrolling in higher education programmes. Nevertheless, this process is not always associated with an increase in per capita GDP, which is often taken as the main indicator of economic

\footnotetext{
${ }^{1}$ These data are used to calculate the indicators shown in Section 2 of this chapter.
} 
success. Figure 1 below, for instance, exemplifies this process with the time series, covering the period 19952006, on the percentage of students over total country populations and the per capita GDP level for five selected OECD countries (namely, France, Italy, the Netherlands, the UK, and the US). ${ }^{2}$

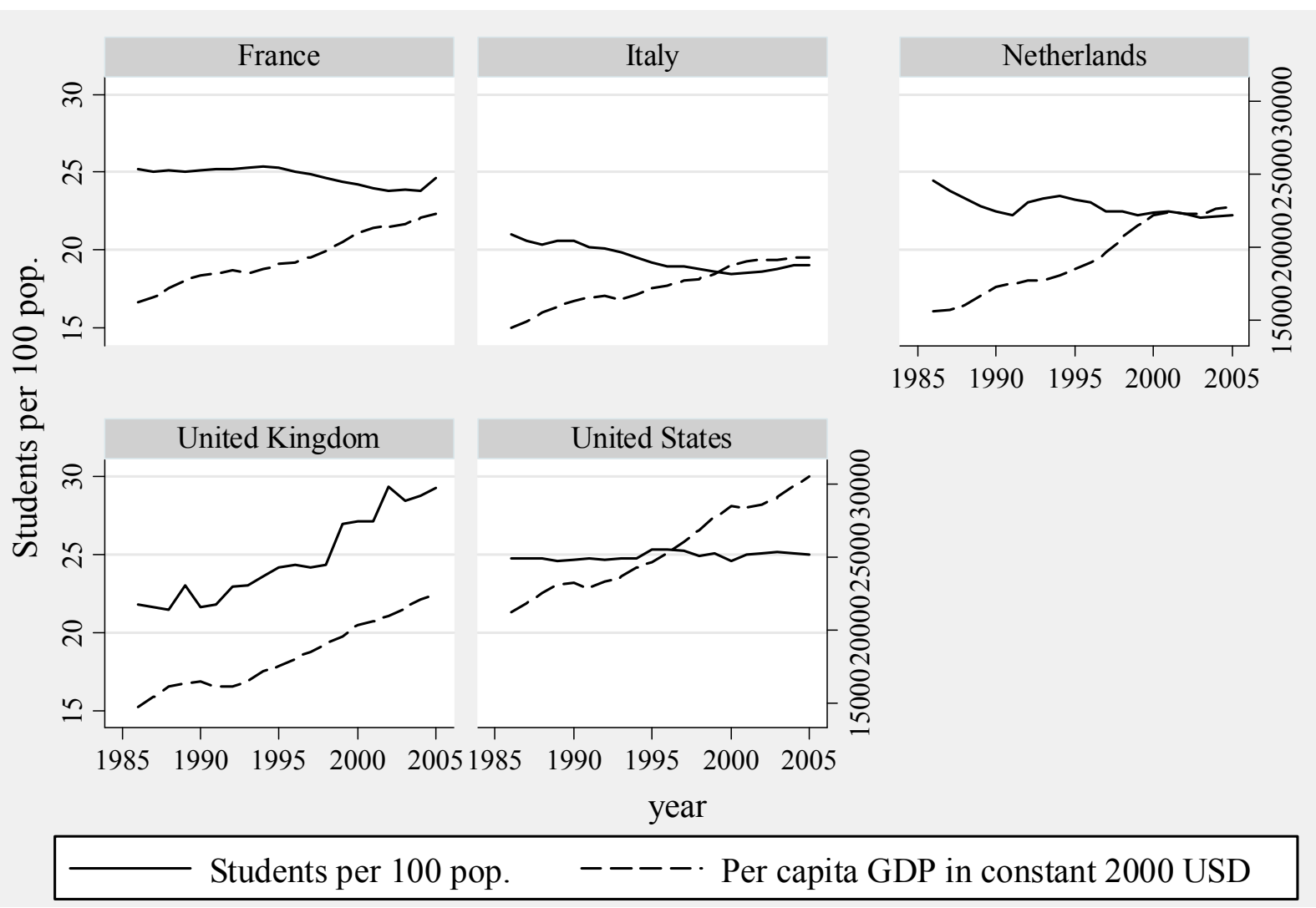

Figure 1. Human capital and per capita GDP in 5 OECD countries, 1995-2006

Source: Raw data from OECD, Authors' calculations.

As can be seen from the figure, in some countries during the last decade the share of citizens actively employed in human capital accumulation actually decreased, mainly because of demographic reasons (i.e. the ageing populations). However, in most OECD countries wealth production increased. The question then would be: "What prompted the increase in GDP not directly attributable to human capital accumulation?" In other countries, GDP grew even without an increase in human capital (e.g. in the US), raising the question "Where do the necessary highly-educated workers come from?".

A partial explanation of this puzzling result lies in the process of concentration of the educated workforce which has been described and explained by the literature on islands of innovation. Recent data sets allow the capture of part of these trends. In particular, the data set assembled by Docquier and coauthors (described in Defoort, 2008) allows the breakdown of country populations in low, medium and high-education, identifying for a subset of rich countries the determinants of human capital accumulation. Table 1 shows data for the same OECD countries shown in Figure 1, and in particular enables the identification of the determinants of all dynamics regarding the accumulation, or de-accumulation, of skilled labour. In fact, these dynamics could be best described with a simple differential equation as follows:

\footnotetext{
${ }^{2}$ The selection of these five countries, maintained throughout this section, is motivated by the need to merge and analyse different data sets, with the aim of obtaining a homogeneous exemplifying data set with comparable data.
} 
$H C_{t}=(1-\delta) H C_{t-1}+\left(M_{H C, t}-X_{H C, t}\right)$,

where $\mathrm{HC}$ stands for the stock of human capital at time $\mathrm{t} ; \delta$ is the gross de-accumulation rate of human capital (i.e. the rate at which local students occupy skilled job posts left vacant by workers exiting from the local labour market); and $(M-X)$ represents the net import rate of skilled workers. Table 1 shows the values of $H C_{t}$, gross skilled emigration rates, and the net human capital accumulation rate for five selected OECD countries. The results show that over the 25 years between 1975 and 2000, the US has been attracting a disproportionate share of the world's skilled labour force, with positive trends to be found also for France.

Table 1 Share of highly-educated population, emigration of skilled workers, and net high education accumulation in five selected OECD countries, 1975-2000

\begin{tabular}{|c|c|c|c|c|c|c|c|}
\hline Variable & Country & 1975 & 1980 & 1985 & 1990 & 1995 & 2000 \\
\hline & United States & $26.30 \%$ & $31.90 \%$ & $35.70 \%$ & $39.20 \%$ & $47.80 \%$ & $51.30 \%$ \\
\hline & United Kingdom & $8.85 \%$ & $10.04 \%$ & $11.90 \%$ & $13.93 \%$ & $15.88 \%$ & $17.82 \%$ \\
\hline \multicolumn{2}{|c|}{ Share of highly-educated citizens Italy } & $4.05 \%$ & $4.73 \%$ & $5.44 \%$ & $6.30 \%$ & $7.80 \%$ & $8.66 \%$ \\
\hline & France & $13.68 \%$ & $16.43 \%$ & $19.17 \%$ & $21.92 \%$ & $24.57 \%$ & $27.92 \%$ \\
\hline & Netherlands & $8.22 \%$ & $10.70 \%$ & $13.18 \%$ & $15.66 \%$ & $19.38 \%$ & $21.86 \%$ \\
\hline \multirow{5}{*}{ High education emigration } & United States & $0.4 \%$ & $0.4 \%$ & $0.4 \%$ & $0.4 \%$ & $0.3 \%$ & $0.3 \%$ \\
\hline & United Kingdom & $19.9 \%$ & $17.9 \%$ & $16.3 \%$ & $15.7 \%$ & $12.6 \%$ & $14.3 \%$ \\
\hline & Italy & $12.7 \%$ & $12.1 \%$ & $10.9 \%$ & $10.0 \%$ & $7.9 \%$ & $8.3 \%$ \\
\hline & France & $1.6 \%$ & $1.7 \%$ & $1.7 \%$ & $1.8 \%$ & $1.6 \%$ & $1.7 \%$ \\
\hline & Netherlands & $15.8 \%$ & $14.0 \%$ & $10.9 \%$ & $9.9 \%$ & $7.5 \%$ & $7.6 \%$ \\
\hline \multirow{5}{*}{ Net high education accumulation } & United States & - & $5.49 \%$ & $3.67 \%$ & $3.35 \%$ & $8.46 \%$ & $3.33 \%$ \\
\hline & United Kingdom & - & $-0.57 \%$ & $0.06 \%$ & $0.09 \%$ & $-0.24 \%$ & $-0.06 \%$ \\
\hline & Italy & - & $0.16 \%$ & $0.14 \%$ & $0.27 \%$ & $0.87 \%$ & $0.24 \%$ \\
\hline & France & - & $2.53 \%$ & $2.47 \%$ & $2.42 \%$ & $2.26 \%$ & $2.96 \%$ \\
\hline & Netherlands & - & $1.18 \%$ & $0.98 \%$ & $1.04 \%$ & $2.17 \%$ & $1.03 \%$ \\
\hline
\end{tabular}

Source: Defoort (2008); Authors' calculations.

Not only do countries perform differently; also, within countries regional education scores show increasing differentials. In order to illustrate possible time trends in the concentration of the skilled labour force in Europe, Figures 2a and 2b (first shown in Caragliu and Nijkamp, 2011) indicate, respectively, a time series of the Krugman Specialization Index ${ }^{3}$ and the Fractionalization Index ${ }^{4}$ The first index (Krugman, 1981) measures the extent to which an area's specialization pattern (in the original version of the index), or any space-varying characteristic, differs from those of a comparison group of areas. The second index (Alesina et al., 2003) gauges the extent to which sub-areas within a larger space are heterogeneous across some dimensions. We measure regional human capital as the regional labour force (in European NUTS1 regions ${ }^{5}$ ) with ISCED 5 and 6 education. ${ }^{6}$

\footnotetext{
${ }^{3}$ Here the Krugman Specialization Index is calculated as in Midelfart-Knarvik and Overman (2002). Our modified version does not capture sectoral issues; therefore, it does not satisfy all properties of the original index, which include assuming a maximum value of 2 .

${ }^{4}$ Atlas Narodov Mira (1964); the index is calculated as the sum of the absolute differences in human capital intensity between each NUTS region and the average EU27 level, the latter being 1 minus the Herfindahl index of educated labour force.

${ }^{5}$ The sample comprises all EU27 NUTS1 regions, except the Bulgarian regions, for which data on human capital attainments prior to 2006 are not available. The NUTS1 level of aggregation is chosen, as Germany and the UK only release data at this level.

6 "The International Standard Classification of Education (ISCED) was designed by UNESCO in the early 1970's to serve 'as an instrument suitable for assembling, compiling and presenting statistics of education both within individual countries and internationally'. It was approved by the International Conference on Education (Geneva, 1975), and was subsequently endorsed by UNESCO's General Conference when it adopted the Revised Recommendation concerning the International Standardization of Educational Statistics at its twentieth session (Paris, 1978)" (from unesco.org).
} 
Results of these calculations clearly show an increasing trend in concentration using two indicators that are frequently adopted to capture within-country differences in regional endowments of human capital. In fact, they show that in the first years of the $21^{\text {st }}$ century fewer regions attract an increasingly larger share of skilled workers.

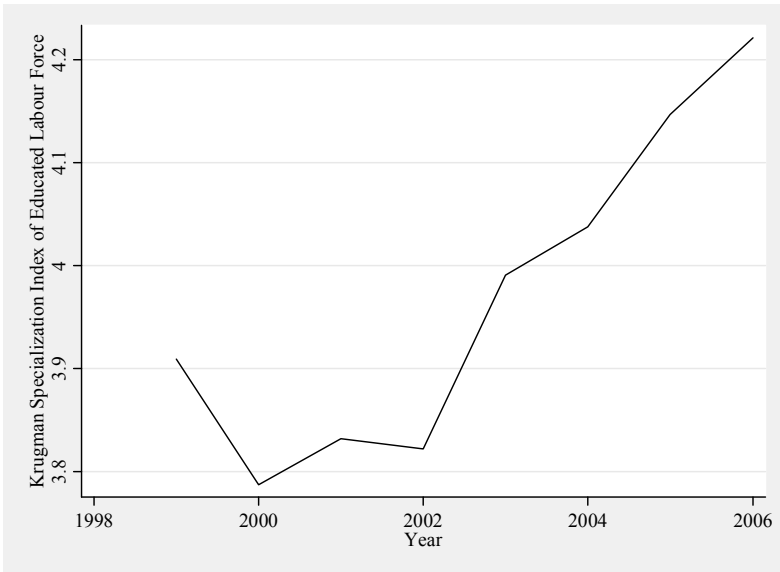

Figure 2a. Krugman Specialization Index for the educated labour force, NUTS1 regions

Source: EUROSTAT, 1999-2006 data, own calculations.

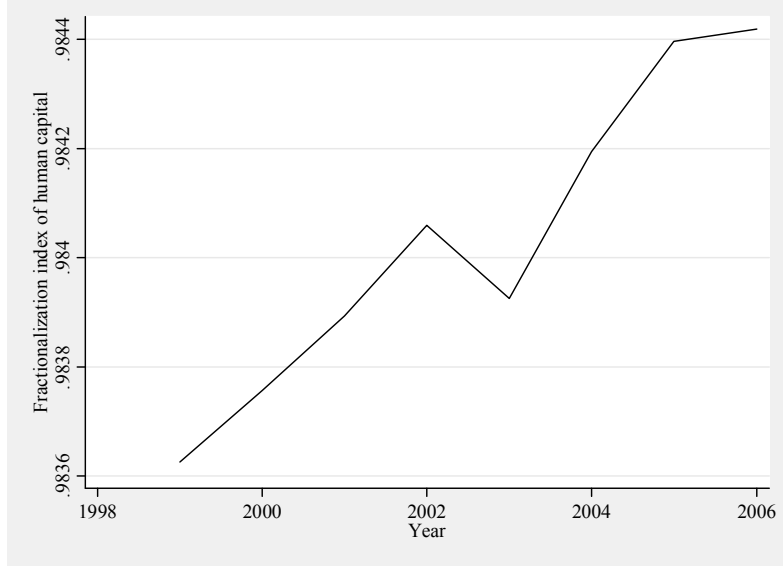

Figure 2b. Fractionalization Index for the educated labour force, NUTS1 regions

Source: EUROSTAT, 1999-2006 data, own calculations.

Source: Caragliu and Nijkamp (2011).

The above mentioned figures clearly suggest that some major trends are taking place in Europe:

- Western countries tend to attract an increasing share of the world's stock of skilled workers, with the traditional motivation of salary differentials as the main push factor. ${ }^{7}$ Among rich countries, the United States tend to attract a larger share of skilled labour than most OECD competitors;

- Within rich countries, richer and more human capital-intensive regions tend to attract a disproportionate share of skilled labour, thereby further augmenting regional disparities, therefore creating potential threats to sending regions.

In Caragliu and Nijkamp (2011) we interpreted these stylized facts, clearly calling for sound empirical research, undertaken through the lens of the Lucas (1988) growth model. In this chapter we briefly review the way the Lucas model has been adapted to a regional setting (Section 3), the results of that empirical analysis (Section 4), and, finally, we interpret those results in light of the ensuing policy implications (Section 5).

\section{The Lucas growth model from a regional perspective}

The Lucas growth model was originally conceived more as a theoretical an applied model. However, in Caragliu and Nijkamp $(2009,2011)$, we show that an endogenous growth model with a cognitive capital externality can generate increasing returns to physical production factors even in a regional setting. In the original Lucas (1988) model, the mechanism driving the emergence of increasing returns to physical factors is the average human capital in a society or area: people enjoy positive spillovers from fellow members of

\footnotetext{
${ }^{7}$ Gibson and McKenzie (2011) show that skilled workers from developing countries experience a net salary differential equal to about 40,000 to 60,000 USD.
} 
the same social group, thus becoming more productive themselves. In our version of the model, the mechanism that produces increasing returns is the presence of higher cognitive capital.

In Caragliu and Nijkamp (2011), we defined cognitive capital (in the spirit of Uphoff, 1999) as "the set of mental processes, reinforced by culture and ideology, in particular encompassing norms, values, attitudes, and beliefs that positively contribute to cooperative behavior and mutually beneficial collective action". We therefore assume that people benefit from positive externalities from cognitive capital. In an environment that is endowed with fluent interpersonal relationships, where people trust each other, tolerance for diversity enhances creativity, and governance of cultural and natural institutions is able to properly manage public endowments, people are expected to gain more than proportionally in productivity. This is in line with the concept of islands of innovation.

The details of the model can be found in the cited works. For our analysis, it suffices to recall that the underlying preferences over consumption are described by a Constant Elasticity of Substitution (CES) function of the usual form:

$U_{0}=\int_{0}^{\infty} \frac{c_{t}^{1-\sigma}-1}{1-\sigma} e^{-(\rho-\lambda)} d t$

where $\sigma-1$ measures the intertemporal elasticity of substitution, and $\rho$ is a discount rate. In the Lucas model, labour productivity is raised not only by individual human capital but also as a result of the increase in the aggregate level of human capital. Analogously, when considering their time allocations, agents do not take into account the possible positive spillovers from their collective behaviour. Aggregate cognitive mechanisms, in the form of improved mutual understanding (e.g. district economies), thick and dense social networks (relational capital), wise management of collective goods that prevents spoiling natural resources, and the efficient transfer of R\&D results, all combine as a cognitive catalyst that optimizes the combination of physical factors and generates increasing returns. Therefore, it is not just aggregate human capital that determines the generation of increasing returns to individual education, but also the regional endowment of cognitive capital.

The model for the individuals in this economy is:

$y_{r, t}=A k_{i, r, t}^{\alpha}\left(u h_{i, r, t}\right)^{1-\alpha}$,

where $y_{r, t}$ measures regional GDP; eq. (3.) is therefore the production function for this model.

Our aggregate economy is described by the following equation:

$y_{r, t}=A k_{r, t}^{\alpha}\left(u h_{r, t}\right)^{1-\alpha} c c_{r, t}^{\eta}$,

where $0<\alpha<1$; and $A, k, u$ and $h$ are defined, respectively, as the technology parameter, the stock of capital (which we estimate with the perpetual inventory $\operatorname{method}^{8}$ ), the share of time devoted to working, and the stock of human capital (i.e. education) of an individual (or in a region); here $c c$ is a measure of cognitive capital. Equation (4.) differs from eq. (3.) in that in eq. (4.) agents are averaged out at the regional level. The crucial assumption of the empirical component of our paper is that individuals create collective (i.e. regional) cognitive capital when investing in their own education.

\footnotetext{
${ }^{8}$ The assumptions include a depreciation rate equal to 2.5 per cent, while the starting point of the capital stock time series is 1998 .
} 
Equation (3) is the basis for our micro-regressions; equation (4) is instead the baseline functional form for regional regressions. In this chapter we briefly review (Section 4) the results of this empirical exercise, which aims at assessing the relative importance of individual education decisions on regional performance, through the use of the Lucas (1988) growth model in a regional setting; region-specific characteristics (viz. cognitive capital) are demonstrated to affect the formation of islands of innovation, and policy implications are derived (Section 5).

\section{The data set and empirical estimates}

To test the above model calls for extensive data. We built a comprehensive data set on European regions by combining EUROSTAT data for the quantitative variables in the Lucas model and European Values Study (henceforth, $\mathrm{EVS}^{9}$ ) data for the cognitive elements of regional knowledge systems. All data cover a crosssection of the year 2000: this choice is motivated by the availability of EVS data for that year. ${ }^{10}$ Table 2 shows the main sources of our data set. The top section of the table shows the main variables used to test the Lucas model in an individual setting (eq. 3); the central part of the table shows data for the aggregate setting test (eq. 4); and, finally, the bottom part of the table shows the cognitive capital measures.

Table 2. The data set

\begin{tabular}{lc}
\hline Data description & Source \\
\hline \hline Household real income & EVS \\
Household education level & EVS \\
Household stock of capital/savings & EVS \\
Share of time devoted to work activities & EVS \\
\hline Regional GDP in constant 2000 prices & EUROSTAT \\
Regional investments (yielding the capital stock with the perpetual inventory method) & EUROSTAT \\
Regional human capital: share of human resources in Science and Technology & EUROSTAT \\
\hline Cognitive capital elements (norms, values, attitudes and beliefs) & EVS \\
\hline Source: Caragliu and Nijkamp (2011). &
\end{tabular}

The individual household test was carried out on 16,929 observations in the EVS data set, which are those in the EU27 for which we have answers to all four questions related to the Lucas model (Table 3).

Table 3. EVS questions chosen to test the Lucas model at the individual household level

\begin{tabular}{|c|c|c|}
\hline Variable & EVS id & Question \\
\hline Household real income & Q110 (v320) & $\begin{array}{l}\text { Here is a scale of incomes and we would like to know to } \\
\text { what group your household belongs, counting all wages, } \\
\text { salaries, pensions and other income that comes in. Just } \\
\text { give the letter of the group your household falls into, after } \\
\text { taxes and other deductions. ( } 1 \text { to } 10 \text { scale) }\end{array}$ \\
\hline Household education level & Q94 (v304) & $\begin{array}{l}\text { What is the highest level you have reached in your } \\
\text { education? ( } 1 \text { to } 8 \text { scale) }\end{array}$ \\
\hline Household stock of capital/savings & Q110a (o49) & Socio-economic status of the respondent ( 1 to 4 scale $)^{12}$ \\
\hline
\end{tabular}

\footnotetext{
${ }^{9}$ EVS consists of a set of individual questionnaires administered to European citizens. Data were collected in four waves: this paper uses the 1999-2000 wave, as it is the first to comprehensively cover the regional dimension of the analysis. Information on methods of data collection and on data stratification are available at:

www.europeanvaluesstudy.eu.

${ }^{10}$ A fourth wave of the EVS has recently become available. Individual interviews were administered in the 2008-2009 period. Therefore, the use of such data would induce a simultaneity issue with the dependent variables being explained with our model.

${ }^{11}$ The choice of indicators is explained in detail in the cited work. The chosen EVS questions are reported as an Appendix.

12 This is essentially a proxy for the extent of household savings, based on the assumption that the socio-economic status of the respondent crucially depends on his/her wealth.
} 
Share of time devoted to work $(\mathrm{u}) \quad$ Own calculation $\quad$ Obtained as 1-Q93(v303 $\left.{ }^{13}\right) / 80$

Units of effective labour Own calculation Obtained as $\mathrm{u}^{*} \mathrm{Q} 94(\mathrm{v} 304)$

Source: Caragliu and Nijkamp (2011).

The estimation of this model is carried out with a three-stage procedure. First, micro-regressions are run on a sample of 16,929 individual observations for which the EVS data set covers the whole spectrum of relevant variables. These observations are then aggregated to form a sample of 261 NUTS2 regions of the European Union. These regional data are used for standard OLS regressions, and - in the third stage - in a Spatial Durbin (henceforth, SDM) model, which generalizes the spatial connectivity effects among spatial units. Estimates are based on Le Sage and Pace (2009), ${ }^{14}$ which enables us to break down the general impacts of the model variables into direct, indirect, and total effects. ${ }^{15}$ The results of this third set of estimates are presented in Table 4.

The total impacts of the model variables show that the regional stock of cognitive capital is indeed positively associated with a higher per capita GDP. This result comes from a positive, but smaller, direct effect and a positive, but not fully significant, indirect effect. This implies that processes of spatial concentration of nonmaterial growth-enhancing characteristics could indeed foster the emergence of islands of innovation, where the returns to skilled labour are maximized not only by the local concentration of human capital, but also because of accessibility to neighbouring regions similarly endowed with skilled labour.

These estimates are based on a geographical connectivity matrix, where pure geographical distance drives the extent to which regions with a high density of highly-skilled labour benefit from being close to regions similarly rich with human capital. However, one major step forward in assessing whether real transfer of knowledge from these splendidly isolated regions to lagging areas takes place could be the use of nongeographical (e.g. relational, social, technological, and cognitive) forms for the connectivity matrix. Alternatively, the focus could be on selected sub-samples of star scientists, following their careers, and assessing their capability to bring in knowledge when moving across space (Trippl, forthcoming).

\footnotetext{
${ }^{13}$ Question Q93 (v303) is: "At what age did you (or will you) complete your full-time education, either at school or at an institution of higher education? Please exclude apprenticeships"; 80 years is the assumed life expectancy at birth for all EU citizens.

${ }^{14}$ Recent empirical applications of this estimator include Fischer et al. (2009) and Del Bo and Florio (forthcoming).

15 "Direct effects estimates measure the impact of changing an independent variable on the dependent variable of a spatial unit. This measure includes feedback effects, i.e., impacts passing through neighboring units and back to the unit that instigated the change. Indirect effects estimates measure the impact of changing an independent variable in a particular unit on the dependent variable of all other units" (Elhorst, 2010, p. 2).
} 
Table 4. Estimation results for eq. (4), using a spatial Durbin model, with country fixed effects

\begin{tabular}{|c|c|}
\hline Dependent variable: $\log$ of per capita $G D P$ & $\begin{array}{c}\text { Spatial Durbin estimates } \\
(1)\end{array}$ \\
\hline Stock of capital & $\begin{array}{l}0.10^{* * *} \\
(0.000)\end{array}$ \\
\hline Units of effective labour & $\begin{array}{c}0.08 \\
(0.25)\end{array}$ \\
\hline Cognitive capital & $\begin{array}{l}0.04 * * \\
(0.03)\end{array}$ \\
\hline Constant term & $\begin{array}{l}8.29 * * * \\
(0.000) \\
\end{array}$ \\
\hline \multicolumn{2}{|c|}{ Spatial autocorrelation coefficients } \\
\hline$\rho$ & $\begin{array}{l}-0.05 \\
(0.47)\end{array}$ \\
\hline $\mathrm{W}^{*}$ Stock of capital & $\begin{array}{c}0.05 \\
(0.23)\end{array}$ \\
\hline W*Units of effective labour & $\begin{array}{c}0.16 \\
(0.34)\end{array}$ \\
\hline $\mathrm{W}^{*}$ Cognitive capital & $\begin{array}{c}0.07 \\
(0.18) \\
\end{array}$ \\
\hline \multicolumn{2}{|l|}{ Direct effects } \\
\hline Stock of capital & $\begin{array}{l}0.10^{* * *} \\
(0.000)\end{array}$ \\
\hline Units of effective labour & $\begin{array}{c}0.08 \\
(0.29)\end{array}$ \\
\hline Cognitive capital & $\begin{array}{l}0.04 * * \\
(0.03) \\
\end{array}$ \\
\hline \multicolumn{2}{|c|}{ Indirect effects } \\
\hline Stock of capital & $\begin{array}{c}0.04 \\
(0.22)\end{array}$ \\
\hline Units of effective labour & $\begin{array}{c}0.15 \\
(0.37)\end{array}$ \\
\hline Cognitive capital & $\begin{array}{c}0.06 \\
(0.22) \\
\end{array}$ \\
\hline \multicolumn{2}{|l|}{ Total effects } \\
\hline Stock of capital & $\begin{array}{l}0.15^{* * *} \\
(0.001)\end{array}$ \\
\hline Units of effective labour & $\begin{array}{c}0.23 \\
(0.22)\end{array}$ \\
\hline Cognitive capital & $\begin{array}{l}0.11^{* *} \\
(0.05) \\
\end{array}$ \\
\hline Country dummies & Yes \\
\hline$R^{2}$ & 0.95 \\
\hline Adjusted $R^{2}$ & 0.94 \\
\hline Log likelihood & 167.97 \\
\hline Number of obervations & 261 \\
\hline
\end{tabular}

Notes: *: significant at the $90 \%$ confidence level; **: significant at the 95 confidence $\%$ level; ***: significant at the 99\% confidence level. P-values in parentheses.

Source: Caragliu and Nijkamp (2011).

\section{Policy implications}

In a previous study (Caragliu and Nijkamp 2011), the authors showed how encompassing spatial spillover effects in regional estimates of the Lucas growth model allows us to account for the potential access to external knowledge even for regions which have low densities of their own skilled labour. In this section we analyse this result in the light of recent EU policies, and show that ignoring potential connectivity effects in shaping policies for human capital and innovation may be a cause of biased policy decisions. 
The EU recently re-launched the Lisbon Agenda with the EU2020 strategy, aiming at fostering the evolution of Europe towards becoming a "smart, sustainable and inclusive economy". ${ }^{16}$ This general objective is specified in five more detailed goals by 2020 :

- 75 per cent of the 20-64 year-olds should be employed (employment target);

- 3 per cent of the EU's GDP (public and private combined) should be invested in R\&D (R\&D target);

- greenhouse gas emissions should be decreased by 20/30 per cent with respect to the 1990 value, while at the same time obtaining 20 per cent of total energy consumption from renewables and obtaining a 20 per cent increase in overall energy efficiency (climate change/energy targets);

- school drop-out rates should be reduced below $10 \%$ while at least 40 per cent of 30-34-year-old citizens should be completing tertiary-level education (education targets);

- finally, at least 20 million fewer people should be in, or at risk of, poverty and social exclusion (poverty/social exclusion targets).

Our work contributes to the debate on two of the above-mentioned five targets, viz. the discussion on innovation/R\&D and education. Our empirical results show in fact that ignoring spillover effects in the assessment of the impact of concentrating skilled labour may in fact blur our understanding of the likely spatial effects of policies which target education and R\&D.

In order to get a quantitative assessment of the likely distortion stemming from not using the appropriate techniques, we proceed as follows. First, we estimate the model explained in Section 3 with OLS, calculating the predicted per capita GDP. Then, we repeat the exercise with the SDM, once again calculating the predicted values of regional per capita GDP. The two vectors of predicted GDPs are then compared region by region. Table 5 shows the top and bottom ten regions in terms of this discrepancy, and identifies a clear pattern: regions in the core of Europe enjoy potentially higher benefits just from being located in macroareas with a high density of skilled labour, whereas regions in New Member States suffer from the opposite effect. Interestingly, geographically remote areas also seem to benefit from their potential accessibility to skilled labour of relatively close regions (this is for instance the case of Valle d'Aosta, Corsica, Västsverige, and Notio and Voreio Aigaio). The poor performance of standard linear predictions for Eastern regions is particularly evident in Figure 5, where the whole set of regional discrepancies is mapped. Dark grey colours indicate regions where GDP levels predicted with OLS estimates are higher than SDM predictions; light grey to white colours indicate the opposite case.

Table 5. The top and bottom regions by difference between per capita GDP predicted with OLS and Spatial Durbin estimates

\begin{tabular}{clc}
\hline NUTS2 code & NUTS2 name & $\begin{array}{c}\text { Difference between SDM } \\
\text { and OLS estimates }\end{array}$ \\
\hline \hline LU & Luxembourg (Grand-Duché) & $15.93 \%$ \\
IE01 & Border, Midlands and Western & $13.06 \%$ \\
ES42 & Castilla-la Mancha & $12.08 \%$ \\
ITC2 & Valle d'Aosta/Vallée d'Aoste & $11.73 \%$ \\
NL42 & Limburg (NL) & $10.31 \%$ \\
FR83 & Corsica & $9.98 \%$ \\
SE07 & Västsverige & $7.94 \%$ \\
GR42 & Notio Aigaio & $7.91 \%$ \\
BE35 & Namen/Namur & $7.87 \%$ \\
GR41 & Voreio Aigaio & $7.85 \%$ \\
\hline RO03 & Nord-Est & $-11.68 \%$ \\
CZ08 & Moravskoslezsko & $-12.14 \%$ \\
\hline
\end{tabular}

${ }^{16}$ The details of this strategy can be found at the URL http://ec.europa.eu/europe2020/index_en.htm. 


\begin{tabular}{cll} 
BG12 & Severen tsentralen & $-12.33 \%$ \\
BG22 & Yugozapaden & $-12.91 \%$ \\
LT & Lithuania & $-13.10 \%$ \\
RO01 & Nord-Vest & $-14.51 \%$ \\
BG23 & Yuzhen tsentralen & $-14.65 \%$ \\
LV & Latvia & $-15.38 \%$ \\
RO08 & Vest & $-18.68 \%$ \\
BG21 & Yugoiztochen & $-18.96 \%$ \\
\hline
\end{tabular}

Source: Authors' calculations.

Figure 2. Percentage difference between OLS and Spatial Durbin estimates of per capita GDP levels in 2000

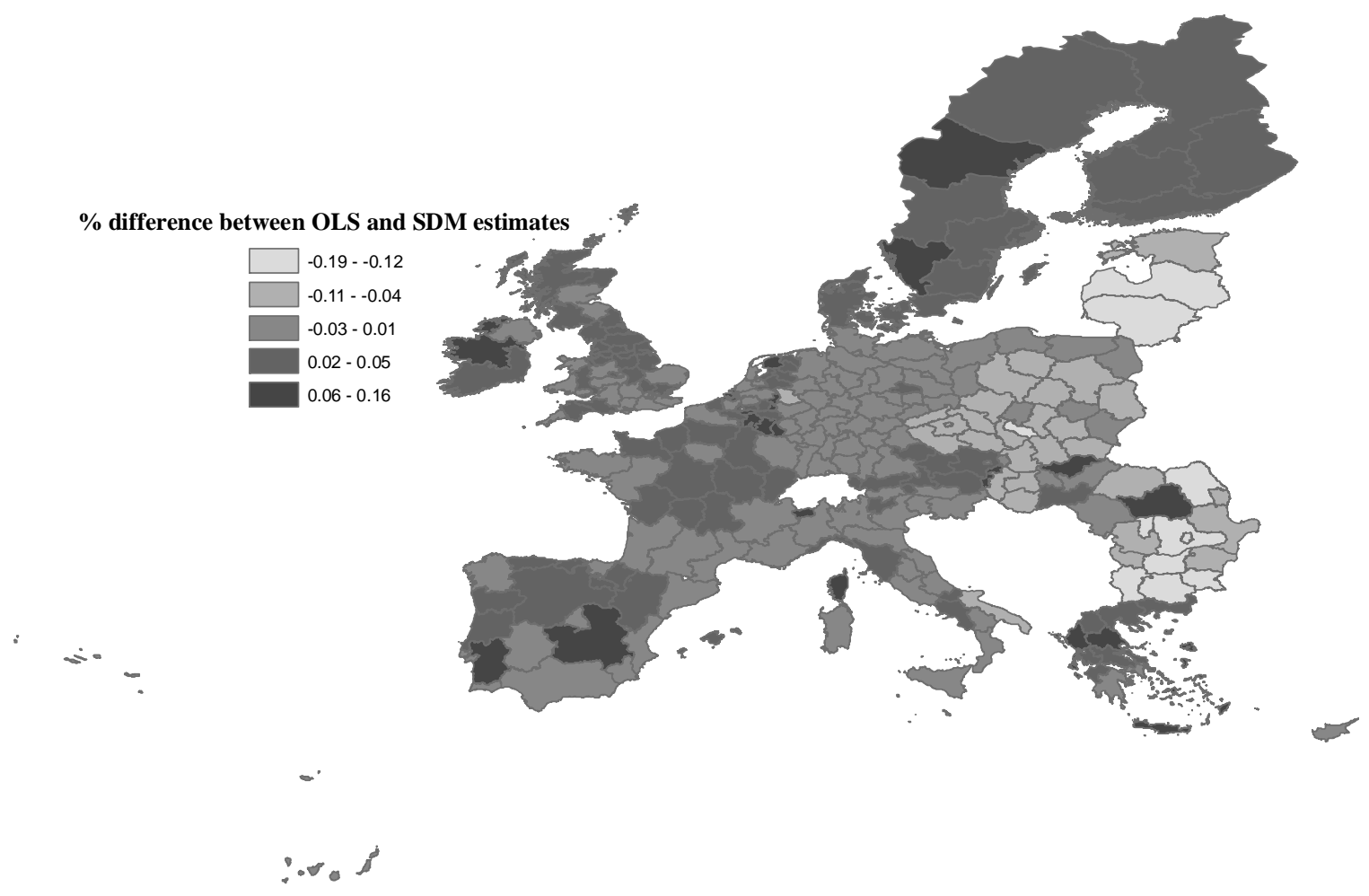

Source: Authors' calculations.

The appearance of the map in Figure 5 crucially depends on the adoption of a geographical connectivity matrix, which translates the effects of underlying real economic interactions (networks of relations and citations, and social, technological, and cultural proximity) into tractable equations. Ertur and Koch (2011) state that "[the definition of] connectivity (...) is much broader and can be generalized to any network structure to reflect any kind of interactions between observations. (...) By analogy to Akerlof (1997), countries may be considered as located in some general socio-economic and institutional or political space, defined by a range of factors. Implementation of spatial methods thus requires accurate identification of their localisation in such a general space. Ideally, such a matrix should be theory-based, but this is beyond the scope of the present paper" (p. 236).

The need to consider other forms of proximity in regional studies has been advocated from a number of different theoretical perspectives using complementary (or alternative) specifications with respect to physical distance. These include relational proximity (Boschma, 2005; Capello, 2007, 2009), organizational proximity (Bellet et al., 1993), social proximity (Rallet and Torre, 1995), institutional proximity (Lundvall and Johnson, 1994), technological proximity (Canter and Meder, 2007), and specialization proximity (Ciccone, 2002; Henderson, 2003). 
Recent empirical studies take this idea seriously (see for example Maggioni and Uberti, 2009; Mora and Moreno, 2010; Basile et al., 2011; Autant-Bernard and LeSage, 2011; Frenken et al., 2010). Within the framework of the present analysis, examining the real mechanisms driving connectivity between regions in the transmission of knowledge spillovers effects may be crucial in making a correct inference about the likely policy effects.

\section{Conclusions}

This chapter starts from the empirical findings in Caragliu and Nijkamp (2011) in order to review the concept of "island of innovation" (a spatial singularity where high-skilled labour tends to concentrate over time). Current statistics demonstrate that indeed, because of higher returns to education and skills which characterize these high-performance regions, skilled labour is increasingly concentrating, thereby posing major challenges for sending regions and countries.

In this chapter we review this process through the lens of the Lucas (1988) growth model, which is adapted to a regional setting by introducing the concept of cognitive capital. The set of social capital skills needed to properly interpret, decode, and fully understand reality is typical of local societies, which vary region by region, and cannot therefore freely move across space. This creates scope for local economies of scale in the formation of increasing returns to regional education and fosters the emergence of islands of innovation. Because sending regions may face several negative outcomes of such a concentration process, in this chapter we propose the concept of "hub of innovation". To some extent, hubs of innovation may be compared to islands of innovation, but the main difference between these two concepts lies in the consistently higher degree of connectivity of the former vis-à-vis the latter.

In fact, our empirical estimates show that connectivity between regions matters in explaining the ease with which knowledge travels across space. One way to avoid the negative consequences from this process of increasing concentration of skilled labour is therefore to foster the creation of nodes of connection between hubs of innovation and sending regions. Whilst in fact the case for concentrating where education is paid its highest return cannot be successfully opposed in a market economy, policies aiming at increasing the exchange of knowledge across space are much more feasible.

Any such policy should carefully consider the true channels through which knowledge travels. Although that type of analysis goes beyond the scope of this chapter, the authors would welcome the development of any step further in this direction.

\section{References}

Acemoglu, D. (1996). "A microfoundation for social increasing returns in human capital accumulation", Quarterly Journal of Economics, 111 (3): 779-804.

Akerlof, G. A. (1997). "Social distance and social decision”, Econometrica, 65 (5): 1005-1027.

Alesina, A., Devleeschauwer, A., Easterly, W. Kurlat, S., and Wacziarg, R. (2003). "Fractionalization" Journal of Economic Growth,8 (2): 155-194.

Atlas Narodov Mira (1964), Moscow: Miklukho-Maklai Ethnological Institute at the Department of Geodesy and Cartography of the State Geological Committee of the Soviet Union.

Autant-Bernard, C. and LeSage, J. (2011). "Quantifying knowledge spillovers using spatial econometric models", Journal of Regional Science, 51 (3): 471-496.

Basile, R., Capello, R. and Caragliu, A. (2011). "Interregional knowledge spillovers and economic growth: the role of relational proximity", in Kourtit K., Nijkamp P., and Stough R. (eds), "Drivers of innovation, entrepreneurship and regional dynamics", Berlin: Springer Verlag, pp. 21-43. 
Bellet, M., Colletis G. and Lung Y. (1993). "Introduction au numéro special sur l'économie de proximité", Revue d'économie régionale et urbaine, 3: 357-364.

Boschma R.A. (2005). "Proximity and innovation. a critical assessment", Regional Studies, 39 (1): 61-74.

Canter U. and Meder A. (2007). "Technological proximity and the choice of a cooperation partner", Journal of Economic Interaction and Coordination, 2: 45-65.

Capello R. (2007). "Regional economics", London (UK): Routledge.

Capello R. (2009). "Spatial spillovers and regional growth", European Planning Studies, 17 (5): 639-658.

Caragliu, A., Del Bo, C. and Nijkamp, P. (2012). "A map of human capital in European cities", in Van Geenhuizen, M. and Nijkamp, P. (eds). "Creative knowledge cities. Myths, visions and realities", Cheltenham (UK): Edward Elgar.

Caragliu, A. and Nijkamp, P. (2009). "Endogenous regional growth: the role of human and cognitive capital", Studia Regionalia, 23 (2), 9-23.

Caragliu, A. and Nijkamp, P. (2011). "Cognitive capital and islands of innovation: the Lucas growth model from a regional perspective", Tinbergen Institute Discussion Paper TI 2011-116/3.

Ciccone, A. (2002). “Agglomeration effects in Europe” European Economic Review, 46: 213-227.

Defoort, C. (2008). "Tendances de long terme en migrations internationales: analyse à partir de 6 pays receveurs", Population 63 (2): 285-318.

Del Bo, C. and Florio, M. (forthcoming). "Infrastructure and growth in a spatial framework: evidence from the EU regions", European Planning Studies.

Docquier, F., Özden, C., and Peri, G. (2010). "The wage effects of immigration and emigration", NBER Working Paper 16646, National Bureau of Economic Research.

Elhorst, J. P. (2010). "Matlab software for spatial panels", paper presented at the $4^{\text {th }}$ World Conference of the Spatial Econometrics Association (SEA), Chicago, 9-12 June 2010.

Ertur C., and Koch, W. (2011). "A contribution to the Schumpeterian growth theory and empirics", Journal of Economic Growth, 16 (3): 215-255.

Fischer, M., Bartkowska, M., Riedl, A. Sardadvar, S. and Kunnert, A. (2009). The impact of human capital on regional labor productivity in Europe", Letters in Spatial and Resource Sciences, 2 (2): 97-108.

Frenken, K., Ponds R., and van Oort, F. (2010). "The citation impact of research collaboration in sciencebased industries: a spatial-institutional analysis". Papers in Regional Science, 89 (2): 351-371.

Gibson, J. and McKenzie, D. (2011). Eight questions about brain drain”, Journal of Economic Perspectives, 25 (3): 107-128.

Henderson, J.V. (2003). “Marshall's scale economies” Journal of Urban Economics, 43: 1-28.

Hilpert, U. (1992) “Archipelago Europe - Islands of innovation. synthesis report", Prospective Dossier No 1: "Science, Technology and Social and Economic Cohesion in the Community", Commission of the European Communities, Brussels.

Hilpert, U. (forthcoming). "The virtualisation of proximity: building networks among islands of innovation in Europe and the US", Journal of Economic Geography.

Kourtit, K., Nijkamp, P., Lowik, S., Vught, F. Van and Vulto, P. (2011a). "From islands of innovation to creative hotspots", Regional Science Policy and Practice, 3 (3): 145-161.

Kourtit, K., Nijkamp, P., Vught, F. van and Vulto, P. (2011b). "Supernova Stars in Knowledge-Based Regions", in: De Noronha Vaz, T. (ed), Studies on Regional Innovation, Faro (PT): University of the Algarve (forthcoming).

Krugman, P. R. (1981). "Intraindustry specialization and the gains from trade", The Journal of Political Economy, 89 (5): 959-973.

Le Sage, J. and Pace, R. K. (2009). "Introduction to Spatial Econometrics”, Cleveland (OH): CRC Press. 
Lucas, R. E. (1988), “On the mechanics of economic development”, Journal of Monetary Economics, 22 (1): $3-42$.

Lundvall B.-A. and Johnson, B. (1994). "The learning economy”, Journal of Industry Studies, 1 (2): 23-42.

Maggioni, M. and Uberti, E. (2009). "Knowledge networks across Europe: which distance matters?", Annals of Regional Science, 43 (3): 691-720.

Marchiori, L., Shen, I. and Docquier, F. (2009). "Brain drain in globalization: a general equilibrium analysis from the sending countries' perspective", IZA Discussion Paper 4207.

Midelfart-Knarvik, K. H. and Overman, H. G. (2002), "Delocation and European integration", Economic Policy, 35: Web appendix.

Mora, T., and Moreno, R. (2010). "Specialisation changes in European regions: the role played by externalities across regions", Journal of Geographical Systems, 12: 311-334.

Nijkamp, P. (2010). "E pluribus unum”, Region Direct, 2(1): 56-65.

Porter, M.E. (1998). "Clusters and the new economics of competition”, Harvard Business Review, 76: 77-90.

Porter, M.E. (1990). "The competitive advantage of nations", New York (NY): Free Press.

Porter, M.E. (2000). "Locations, clusters, and company strategy", in Clark, G.L., Feldman, M.P. and Gertler, M.S. (eds), The Oxford handbook of economic geography, Oxford (UK): Oxford University Press, pp. 253-274.

Rallet, A. and Torre, A. (eds) (1995). "Économie industrielle et économie spatiale", Paris (FR): Economica.

Rauch, J. E. (1993). "Productivity gains from geographic concentration of human capital: evidence from the cities", Journal of Urban Economics, 34 (3): 380-400.

Saxenian, A. (1994). "Regional advantage: culture and competition in Silicon Valley and Route 128", Cambridge (MA): Harvard University Press.

Tranos, E., Reggiani, A. and Nijkamp, P. (2011). “Accessibility of Cities in the Digital Economy", Cities (forthcoming).

Trippl, M. (forthcoming). "Islands of innovation as magnetic centres of star scientists? empirical evidence on spatial concentration and mobility patterns", Regional Studies: 1-16 (DOI 10.1080/00343404.2011.556613).

Zucker, L.G. and Darby, M. R. (2007). "Star scientists, innovation and regional and national immigration", NBER Working Papers 13547, National Bureau of Economic Research.

\section{Appendix: Selection of cognitive capital indicators from the EVS data set.}

Table A1. Selected questions in the EVS data set

\begin{tabular}{|c|c|c|}
\hline Domain & Question & Scale \\
\hline Community organizational life & $\begin{array}{l}\text { How often is your time spent in clubs and } \\
\text { voluntary associations? }\end{array}$ & $\begin{array}{l}1 \text { every week } \\
2 \text { once or twice a month } \\
3 \text { a few times a year } \\
4 \text { not at all }\end{array}$ \\
\hline Engagement in public affairs & Participation in any social activity & $0-1$ \\
\hline Community volunteerism & $\begin{array}{l}\text { Voluntary work in any community } \\
\text { activity }\end{array}$ & $0-1$ \\
\hline Informal sociability & Agree that "Most people can be trusted" & $\begin{array}{l}1 \text { trust them completely } \\
2 \text { trust them a little } \\
3 \text { neither trust nor distrust them } \\
4 \text { do not trust them very much } \\
5 \text { do not trust them at all }\end{array}$ \\
\hline
\end{tabular}

Source: Caragliu and Nijkamp (2011). 